\title{
Influence of Phytoplankton Lysis or Grazing on Bacterial Metabolism and Trophic Relationships
}

\author{
F. Van Wambeke \\ Microbiologie Marine, C.N.R.S., U.P.R. 223, Campus de Luminy, case 907, 13288 Marseille \\ cedex 9, France
}

Received: 22 May 1993; Revised: 18 October 1993

\begin{abstract}
Experimental microcosms were used to study the dynamics of heterotrophic bacterial populations with respect to phytoplankton loss. In a two-stage linked culture system, we artificially separated production and loss processes of a diatom Phaeodactylum tricornutum. In the first (productive) stage, the algae developed axenically and continuously. The outflow was fluxed in two degradation stages, where phytoplankton-derived detritus resulted respectively from: (1) excretion and by-products of phagotrophic organisms (protozoans), and (2) bacterial degradation through bacterial attachment and lysis. According to the phytoplankton decay mode, i.e., lysis or grazing, bacterial adaptations were different. The study of bacterial productivity and aminopeptidase activity showed specific bacterial evolution during the succession of different prey-predator relationships. The occurrence of aggregates allowed nanoflagellates to develop an alternative diet; they fed not only on bacteria, but also on partially degraded phytoplankton detritus, inducing a strong short-cut in the food chain. Sources and controls of extracellular proteolytic activity are discussed. Such experimental approaches are interesting because they separate bacterial lysis and protozoan grazing of phytoplankton, as well as the fates of their corresponding phytoplankton detritus in the microbial food web.
\end{abstract}

\section{Introduction}

Spring phytoplankton blooms generally cease as rapidly as they appear. Grazing, lysis, and sedimentation are the main factors ending such blooms [24, 47]. Some of these are favored by hydrodynamic singularities [26]. Jumars et al. [22] demonstrated the importance to bacterial growth of by-products resulting from incomplete ingestion, digestion, and absorption during grazing. For zooplankton material is lost through fecal material, excretion, and breakage of prey during feeding. Egested food vacuoles and excretion constitute the means of loss for protozoans. Consequently, in the euphotic zone, grazer by-products and phytoplankton-lysed detritus constitute sources of organic matter for heterotrophic bacteria. During phytoplank- 
ton lysis, microbial succession shows a characteristic aggregation phase $[2,30]$ associated with well-defined attached bacterial populations possessing high growth rates [16, 27] and high capacities to hydrolyse bio-polymers $[14,48]$. Then a disaggregation phase occurs, due to the combined activity of bacteria and protozoans [2]. In contrast, in the case of phytoplankton grazing, Jumars et al. [22] suggest a rapid diffusion away of solutes resulting from incomplete digestion. Furthermore, undigested vacuolar contents issued from protozoan grazing are submicron particles usually classified as dissolved organic matter, i.e., at the opposite end of the particle size spectrum when compared to fresh aggregated phytodetritus.

Polymer hydrolysis is a rate-limiting step in the microbial utilization of organic matter during phytoplankton post-blooms $[4,15]$. Enzymatic activity per cell and bacterial growth rates show complex variations from pre-bloom to post-blooms situations [23]. Thus, bacterial productivity should be strongly dependent on the size distribution of particles and on the composition of the available detrital material. Several questions arise from these hypotheses: (1) Does grazing or lysis degradation processes provide equivalent phytoplankton-derived detritus in terms of availability for heterotrophic bacteria? (2) Are there direct relationships between hydrolytic activity and bacterial productivity? (3) Is bacterial production favored by the pre-digestion of phytoplankton by grazers? and (4) How do heterotrophic nanoflagellates feeding on bacteria interfere during these two decay modes?

Observations in natural conditions do not provide answers to these questions. An experimental study appears to be necessary to differentiate phytoplankton loss processes. For this purpose a two-stage continuous culture system was developed. In the first stage, an axenic, pure culture of Phaeodactylum tricornutum developed in nitrogen-sufficient conditions. This primary production was transferred to a second stage containing natural sea water stored in the dark. This stage comprised two treatments designed to determine the fate of phytoplankton through the microbial food web [1] by differentiating between bacterial lysis and protozoan grazing. The effect of grazing or lysis of $P$. tricornutum on bacterial production, aminopeptidase activity, and trophic relationships was studied throughout the microbial successions occurring in both microcosms.

\section{Materials and Methods}

\section{Microcosm Design}

The two-stage culture system is shown in Fig. 1. In the first stage (P) the $P$. tricornutum was grown axenically in $\mathrm{N}$-sufficient conditions in a 5-liter culture vessel under continuous light at $20^{\circ} \mathrm{C}$. This culture was maintained at a dilution rate of $0.5 \mathrm{day}^{-1}$. The outflow was separated into 3 fractions. One was obtained by a peristaltic pump which ran for $4 \mathrm{~h}(4-8: 00 \mathrm{a} . \mathrm{m}$.) to collect first-stage samples. The 2 other fractions were obtained by a pump which ran from 8:00 a.m. to 4:00 a.m. The first-stage outflow (mean 1 liter per batch and per day) was divided into two 100 -liter batches ( $\mathrm{G}$ and L), pre-filled with 80 liters of filtered sea water. The $\mathrm{L}$ batch was devoted to bacterial lysis of phytoplankton and was filtered ( $5 \mu \mathrm{m}$, cellulose acetate, Sartorius, Göttingen, Germany) to prevent protozoan development. The G batch was devoted to grazing of phytoplankton by protozoans and was filtered only through a $10-\mu \mathrm{m}$ filter (Nuclepore, Cambridge, USA) to permit protozoan growth. Such filtration discarded metazoans, and was intended to obtain the minimum of trophic levels in the protozoan food web. Filtration was by means of a siphon-filter, ensuring no contact with air under the filter and no turbulence [38]. The 2 batches, $\mathrm{G}$ and $\mathrm{L}$, were kept in the dark to avoid any new phototrophic production. Average water 


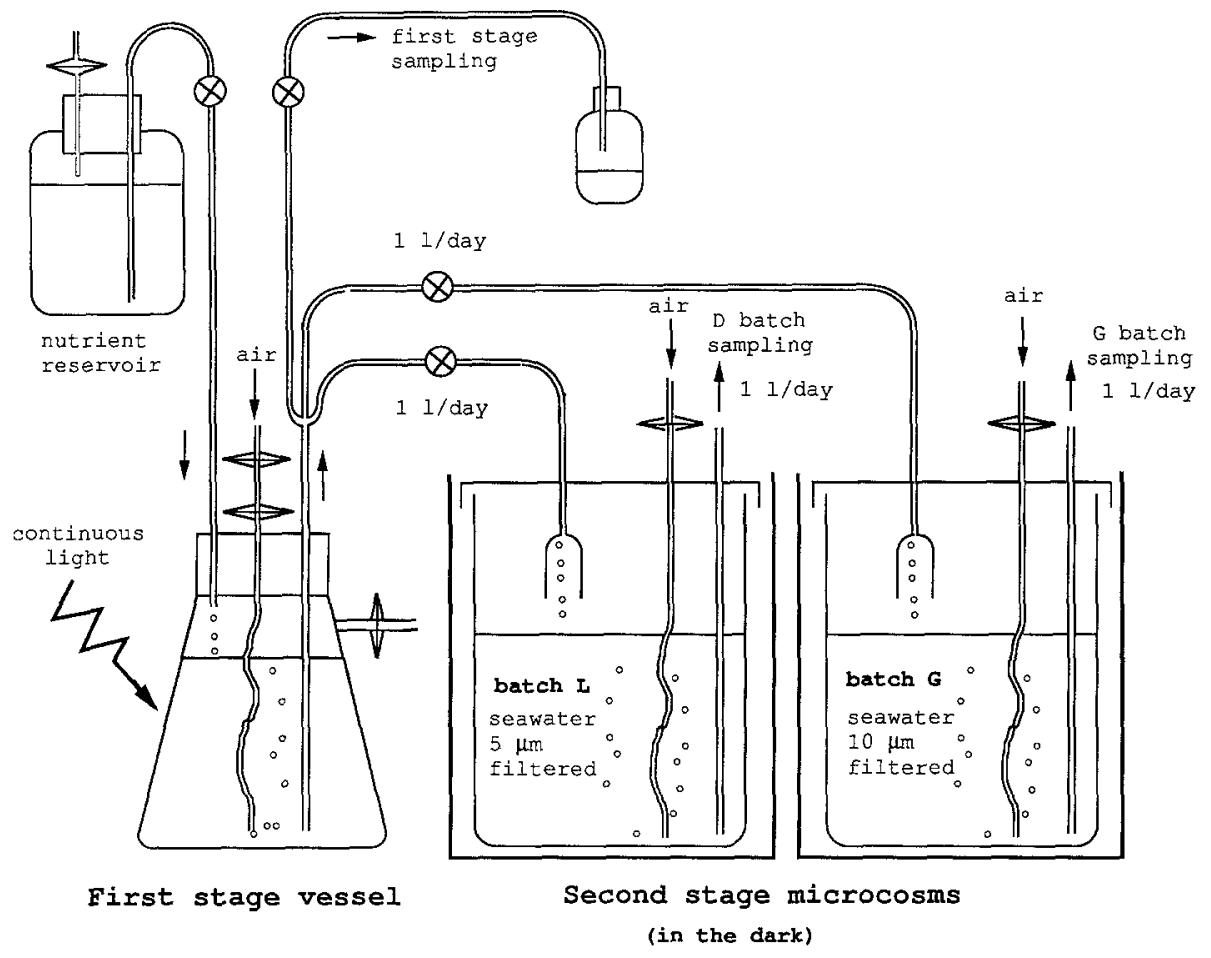

Fig. 1. Schematic diagram of the two-stage experimental system.

temperature was $20^{\circ} \mathrm{C}$. The inflow of 1 liter day ${ }^{-1}$ was counterbalanced by sampling the same volume every day. The experiment lasted 30 days.

\section{Biomass Determinations}

Algae, heterotrophic nanoflagellates, and bacteria were fixed with formalin (final concentration 2\%) and stained with DAPI (final concentration $500 \mu \mathrm{g} \mathrm{liter}^{-1}$ ). Bacteria were filtered through $0.2-\mu \mathrm{m}$ Nuclepore filters and counted according to the technique described by Porter and Feig [32]. Samples were dispersed by sonication ( $75 \mathrm{~W}, 2$ min with a $5-\mathrm{mm}$ probe). Bacterial biovolumes were estimated by sizing width (W) and length (L) of about 150 bacteria from random fields on several slides. Individual biovolumes were calculated as:

$$
\mathrm{Vol}=\pi \times\left(\mathrm{W}^{2} \times \mathrm{L} / 4-\mathrm{W}^{3} / 12\right) .
$$

Algae and heterotrophic nanoflagellates were filtered through $0.8-\mu \mathrm{m}$ Nuclepore filters and counted by epifluorescence microscopy according to the technique described by Sherr and Sherr [40]. The variation coefficient averaged $15 \%$ for counts. Nanoflagellates were classified into different categories according to their size and morphology during counting with an ocular micrometer. Variation coefficient (VC) averaged $15 \%$ for counts.

\section{Bacterial Production}

Bacterial production was estimated daily by the thymidine (Tdr) method [13]. Subsamples (10 $\mathrm{ml})$ were incubated at $20^{\circ} \mathrm{C}$ in the dark for $1 \mathrm{~h}$ after receiving $10 \mathrm{nM}$ [methyl- ${ }^{3} \mathrm{H}$ ]thymidine $(83 \mathrm{Ci}$ $\mathrm{mmol}^{-1}$ ). A killed control was prepared with 5\% trichloracetic acid (TCA). To stop incubation, each 
duplicate was cooled for $5 \mathrm{~min}$ in an ice-water bath, followed by the addition of $1 \mathrm{ml}$ of ice-cold $55 \%$ TCA. The two duplicates and the blank were filtered through Sartorius cellulose acetate filters $(0.2$ $\mu \mathrm{m})$. Filters were rinsed 3 times with $3 \mathrm{ml}$ ice-cold $5 \%$ TCA before radioassaying.

Time course experiments $(0,15,30,60$, and $120 \mathrm{~min})$ performed during the higher activity period demonstrated that $\mathrm{Tdr}$ incorporation was always linear over $1 \mathrm{~h}$ in the two batches. Thymidine saturation was verified 3 times (days 0,7 , and 27), by incubating $\left[{ }^{3} \mathrm{H}\right] \mathrm{Tdr}$ at $2,5,10,15$, and $20 \mathrm{nM}$ final concentration. Isotope dilution was inhibited by using the concentration of $10 \mathrm{nM}$, which was saturating (more than $75 \%$ of the Vmax) in most of the saturation tests performed.

Conversion factors were obtained twice in each batch (days 12 and 25) from simultaneous measurements of $\left[{ }^{3} \mathrm{H}\right] \mathrm{Tdr}$ incorporation in ice-cold TCA, and increase in bacterial biomass in diluted batch cultures; $100 \mathrm{ml}$ of 3- $\mu \mathrm{m}$ filtered $\mathrm{G}$ or $\mathrm{L}$ batches were diluted with $900 \mathrm{ml}$ of particle-free water from the same batch $(0.2 \mu \mathrm{m}$, Sartorius acetate filter).

Empirical conversion factors were calculated during exponential growth by dividing the increase in bacterial biovolume by the integrated $\left[{ }^{3} \mathrm{H}\right] \mathrm{Tdr}$ incorporation [34]. The carbon/biovolume conversion factor was determined from previously published [41] data. Rates of thymidine incorporation were converted to bacterial production using an average conversion factor of $34.4 \mathrm{ng} \mathrm{C} \mathrm{pmol} \mathrm{Tdr}{ }^{-1}( \pm 79 \%$, $n=4)$; this value was used for both batches during all the experiments.

\section{Respiration of Amino Acids}

Ten-milliliter samples of $\mathrm{L}$ and $\mathrm{G}$ batches were sampled daily and inoculated separately with $\left[{ }^{14} \mathrm{C}\right]$ arginine $(10 \mathrm{nM}),\left[{ }^{14} \mathrm{C}\right]$ glutamic acid $(10 \mathrm{nM})$, and $\left[{ }^{14} \mathrm{C}\right]$ leucine $(10 \mathrm{nM})$. After $1 \mathrm{~h}$ of incubation at $20^{\circ} \mathrm{C}$, samples were filtered through $0.2-\mu \mathrm{m}$ Sartorius acetate filters and rinsed 3 times with $0.2-\mu \mathrm{m}$ filtered sea water. The filters were examined with liquid scintillation counting. Respiration was measured by acidifying the filtrate with $\mathrm{H}_{2} \mathrm{SO}_{4}$ and trapping the evolved ${ }^{14} \mathrm{CO}_{2}$ in a phenylethylamine trap. Abiotic adsorption of the label was corrected with formalin-killed controls. One hour was a sufficient incubation time to reach isotopic equilibrium, as verified during three time-course experiments. Respiration percentage was expressed as percentage of total uptake for each amino acid. Difference between duplicates was, on average $11 \%$ of the respiration percentage.

\section{Aminopeptidase Activity}

Aminopeptidase activity was assayed by measuring the production rate of 7 amido 4-methylcoumarin (MCA) from L-leucyl-methylcoumarin-HCl (Leu-MCA) [18]. An aliquot of Leu-MCA stock solution ( $5 \mathrm{~mm}$ in methylcellosolve) was added to $3 \mathrm{ml}$ of sample and gently mixed, yielding a final concentration of $50 \mu \mathrm{M}$ Leu-MCA. Fluorescence intensity was recorded at $365 \mathrm{~nm}$ (excitation) and $445 \mathrm{~nm}$ (emission) in a Kontron, Warford, UK SFM 23 B spectrofluorometer every 5 min during a $30 \mathrm{~min}$ incubation period at $20^{\circ} \mathrm{C}$. As the Leu-MCA concentration employed was $50 \mu \mathrm{M}$, aminopeptidase activity was expressed in terms of potential velocity (nanomoles Leu hydrolyzed per liter per hour).

\section{Bacterial Mortality Rates}

On three occasions (days 4,11 , and 22), bacterial mortality rates were measured in $\mathrm{L}$ and $\mathrm{G}$ batches according to the procedure of Servais et al. [37]. Briefly, we determined the long-term decrease of the radioactivity in the ice-cold TCA precipitate of subsamples, where bacterial populations had previously incorporated $\left[{ }^{3} \mathrm{H}\right]$ thymidine during one day. This decrease in radioactivity was measured in the total sample and in a $2-\mu \mathrm{m}$ pre-filtered $50-\mathrm{ml}$ sample in order to estimate the grazing rate and the residual mortality rate of bacteria. 


\section{Data Analysis}

In an ideal continuous culture, a microorganism changes its abundance according to the equation:

$$
\mathrm{dX} / \mathrm{dt}=\mathrm{D} \times(\mathrm{Xi}-\mathrm{Xo})+\mathrm{K}
$$

where $\mathrm{dX} / \mathrm{dt}$ (cells liter ${ }^{-1}$ day $^{-1}$ ) is the variation rate of cell abundance, $\mathrm{D}$ is the dilution rate of the batch $\left(\right.$ day $\left.^{-1}\right), \mathrm{Xi}$ and $\mathrm{Xo}$ (cells liter ${ }^{-1}$ ) the inflow and outflow cell numbers, respectively. $\mathrm{K}$ corresponds to the sum of biological and physical fluxes inside the culture, i.e., the sum of production sources minus the sum of losses, and consequently represents the net daily variations. Ideally, in stable continuous cultures $\mathrm{dX} / \mathrm{dt}=0$ and the sign of Xo - Xi only determines if the microorganisms are 'consumed' or 'produced.'

In $\mathrm{L}$ and $\mathrm{G}$ batches, $\mathrm{dX} / \mathrm{dt}$ varied, and the following equation was used:

$$
\mathrm{Kx}(\mathrm{i}, \mathrm{j})=\left(\mathrm{XA}_{\mathrm{j}}-\mathrm{XA} \mathrm{A}_{\mathrm{i}}\right) /(\mathrm{j}-\mathrm{i})+\left(\left(1 / \mathrm{V}_{\mathrm{ij}}\right) \times\left[\left(\mathrm{XA}_{\mathrm{j}}+\mathrm{XA}_{\mathrm{i}}\right) / 2-\left(\mathrm{XP}_{\mathrm{j}}+\mathrm{XP}_{\mathrm{i}}\right) / 2\right]\right)
$$

where $X_{j}$ and $X A_{i}$ were the microorganism concentration in the second stage, $X_{j}$ and $X P_{i}$ the microorganism concentration in the first stage on days $j$ and $i$, and $V_{i j}$ the second stage batch volume (liters) between days $\mathrm{i}$ and $\mathrm{j}$.

Bacterial export fluxes ( $\mathrm{F}_{\text {exp }}$, micrograms carbon per liter per hour) were calculated from bacterial production and daily net variations of bacterial biomass as follows:

$$
\mathrm{F}_{\exp (\mathrm{i}, \mathrm{j})}=\mathrm{K}_{\mathrm{ij}} \mathrm{BB}-\left(\mathrm{PB}_{\mathrm{i}}+\mathrm{PB}_{\mathrm{j}}\right) / 2
$$

where $\mathrm{K}_{\mathrm{ij}} \mathrm{BB}$ is the daily net variation of bacterial biomass (micrograms carbon per liter per hour). $\mathrm{PB}_{\mathrm{i}}$ and $\mathrm{PB}_{\mathrm{j}}$ are bacterial productions (micrograms carbon per liter per hour) on days $\mathrm{j}$ and $\mathrm{i}$, respectively. This equation gives an estimate of hourly rates of bacterial export for comparison with rates of bacterial production, but it is estimated from bacterial biomasses estimated daily and assumes linear interpolation of bacterial production between days $i$ and $j$.

Considering a simple prey-predator relationship, instantaneous (daily) carbon gross growth efficiency $\mathrm{Y}$ of a predator $\mathrm{Z}$ feeding on a prey $\mathrm{X}$ can be estimated with calculated daily net variation, if this parameter approximates the true production and losses of the prey and predator, respectively, by the following equation:

$$
\mathrm{Y}=\left(\mathrm{K}_{\mathrm{i}, \mathrm{j}} \mathrm{Z} /\left|\mathrm{K}_{\mathrm{i}, \mathrm{j}} \mathrm{X}\right|\right) \times 100
$$

The daily net variation $\mathrm{K}_{\mathrm{i}, \mathrm{j}} \mathrm{Z}$ is the production rate of the predator (micrograms carbon per liter per day). The daily net variation, $\left|K_{i, j} X\right|$, is the clearance rate of the prey (micrograms carbon per liter per day). Carbon growth efficiencies were estimated only when daily corrected variations (net variations) were high and were supposed to reflect the true gross growth (or grazing rates) of the organisms. For protozoans, carbon equivalent was estimated from abundance and mean biovolume, using a $220 \mathrm{fg} \mathrm{C}$ $\mu \mathrm{m}^{-3}$ ratio [5] as conversion factor. The carbon equivalent for the three size classes of protozoans, I-II-III (bacterial predators, see results), were pooled to estimate daily corrected variation of bacterial predators, termed $\mathrm{K}_{\text {flag }}$. The daily corrected variation of $P$. tricornutum carbon $\left(\mathrm{K}_{\mathrm{Pt}}\right)$ was calculated from $P$. tricornutum abundance, and carbon per cell ratio was calculated from the axenic culture (range 5.3-10.5 pg C algae ${ }^{-1}$ ).

\section{Results}

\section{Microbial Communities}

In batch $L(5-\mu \mathrm{m}$ pre-filtered), the absence of any kind of large protozoan able to graze directly on $P$. tricornutum was confirmed by microscope observations. From days 7 to $11, P$. tricornutum increased in accordance with the theoretical inflow of about $6.2 \times 10^{6}$ cells liter ${ }^{-1}$ day $^{-1}$ (Fig. 2A). Increase in bacterial density coin- 
batch $L$

phytoplankton lysis

phytoplankton grazing
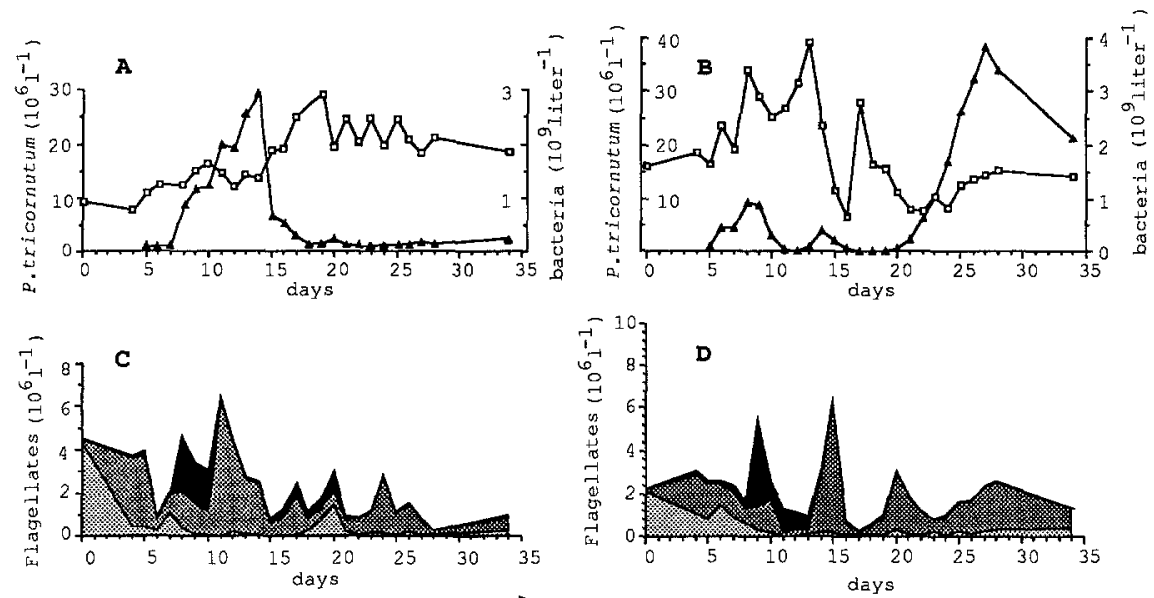

圈 Class I $1,6-3 \mu \mathrm{m}$

图 class II $3-5 \mu \mathrm{m}$

- class III $5-10 \mu \mathrm{m}$

0 group IVa

$\square$ group $\mathrm{IVb}=$ p.tricornutum grazer

group IVC

-o-- class $V>15 \mu m$

- P. tricornutum

- bacteria

Fig. 2. Changes in numbers of microbial populations with time. Batch L (left): decomposition of phytoplankton; batch G (right): grazing of phytoplankton.

cided with $P$. tricornutum enrichment (days 5-10, Fig. 2A). During this period, most of the bacterial population were free-living cells.

After this period, degradation of $P$. tricornutum followed the scheme described by Biddanda and Pomeroy [2]. Initially, aggregates were exclusively composed of $P$. tricornutum cells and bacteria; subsequently, aggregates also included phytodetritus and protozoans (day 8 to 14 ). Bacteria colonizing $P$. tricornutum cells exhibited a specific morphology and attachment mode. They were rod-shaped $(2.3 \times 0.38 \mu \mathrm{m})$ and attached on algal cells only by their poles (spiked-bacteria). This characteristic aspect of attachment has been described by Newell et al. [30] (Caulobacter attached on Thalassiosira cells), and suggested competition for space. This attachment was very strong, as some of them resisted the sonication treatment used for bacterial counts. Bacterial numbers increased during this aggregation phase until day 19.

After the algal peak (days 14 to 17), almost all aggregates disappeared. The algae lost their fluorescence brightness and seemed to have no cytoplasmic content. Such ghost cells were observed during other phytoplankton decomposition experiments $[7,14]$. The phytoplankton then decomposed at the same rate as the inflow flux, as confirmed by the stabilization of algal counts from day 17 . Bacterial counts stabilized at about $2.2 \times 10^{9}$ bacteria liter $^{-1}$, with oscillations $\left(1.7-2.5 \times 10^{9}\right.$ bacteria liter ${ }^{-1}$ ) greater than the bacterial count standard error range (mean $\pm 15 \%$ ). 
The heterotrophic nanoflagellates (HNAN) observed in this batch were almost spherical, with diameters ranging between 1.6 and $10 \mu \mathrm{m}$. Their counts were separated into three size classes: I $(1.6-3 \mu \mathrm{m})$, II $(3-5 \mu \mathrm{m})$, and III $(5-10 \mu \mathrm{m})$. Maximum HNAN counts were obtained at day $11\left(6.3 \times 10^{6}\right.$ liter $\left.^{-1}\right)$ and comprised mostly class II cells (Fig. 2C). The HNAN population decreased rapidly on days 11-15, and then fluctuated until the end of the experiment $\left(0.3-2.8 \times 10^{6}\right.$ HNAN liter ${ }^{-1}$ ). Occasionally (day 20 and 24), HNAN peaks were opposed to those of bacteria, but this was not systematically observed.

In batch $\mathrm{G}$ (protozoan grazing), the microbial community appears morphologically diversified. In addition to the three HNAN size classes observed in batch L, other larger protozoans developed. Grazing of $P$. tricornutum was checked by observation of digestive vacuoles fluorescing red or by an obvious phagocytosis step (half a diatom still visible, partially engulfed by a protozoan). The extreme sizes of protozoans showing such proofs of ingestion were 8 and $14 \mu \mathrm{m}$. Most of these predatory cells were spherical; they constituted the class IVb. Two other morphological types of protozoans were identical in size to those of class IVb, but never presented direct proof of $P$. tricornutum ingestion; one conical protozoan (5-6 $\mu \mathrm{m} \times 10-12 \mu \mathrm{m})$ belonging to class IVa was detected at the beginning of the experiment $\left(10^{5}\right.$ cells liter $\left.{ }^{-1}\right)$, and another one, more spherical $(5.5-7 \mu \mathrm{m} \times 7-9$

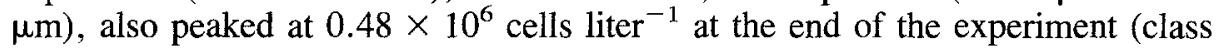
IVc).

Other protozoans (class V) were observed occasionally (Fig. 2E), and their number was estimated approximately $\left(<0.05 \times 10^{6}\right.$ cells liter $\left.^{-1}\right)$, given the imprecision of their counts. Among them, some ciliates (Lhomaniella, F. Rassoulzadegan, pers. comm.) and some amoebic forms (cell $12 \mu \mathrm{m}$ in diameter, pseudopodium 16-24 $\mu \mathrm{m}$ long) were observed.

The microbial succession observed in this batch suggested three main preypredator relationships: class $\mathrm{IVb}$ on $P$. tricornutum, class $\mathrm{V}$ on class $\mathrm{IVb}$ and, classes I, II, and III on bacteria (Fig. 2B,D,E).

\section{Heterotrophic Activity}

Aminopeptidase Activity. Aminopeptidase activity was measured on and after the 7 th day of the experiment. In both batches (Fig. 3A,B), initial activities were low (about $30 \mathrm{nmol}$ Leu liter ${ }^{-1} \mathrm{~h}^{-1}$ ). In the lysis batch L, aminopeptidase activity reached $141 \mathrm{nmol}$ Leu liter $^{-1} \mathrm{~h}^{-}$at day 12 and was sustained up to $125 \mathrm{nmol}$ Leu liter ${ }^{-1} h^{-1}$ for the four following days. In the grazing batch $G$, the peak was later (day 15) but higher (202 nmol Leu liter ${ }^{-1} \mathrm{~h}^{-1}$ ).

When expressed on a per bacterial cell basis, aminopeptidase activity showed more contrasted peaks than when expressed by unit volume (Fig. 3C,D). The aminopeptidase activity/bacterial count ratio was especially enhanced in grazing batch $\mathrm{G}$ since the highest aminopeptidase activity corresponded to a strong decrease in bacterial numbers.

Respiration of Amino Acids. Among the three amino acids tested, glutamic acid, which is more representative of maintenance metabolism, was more mineralized (Fig. 4). A progressive increase in the respired fraction was observed in batch $\mathrm{L}$ 
batch $L$ phytoplankton lysis batch $G$ phytoplankton grazing

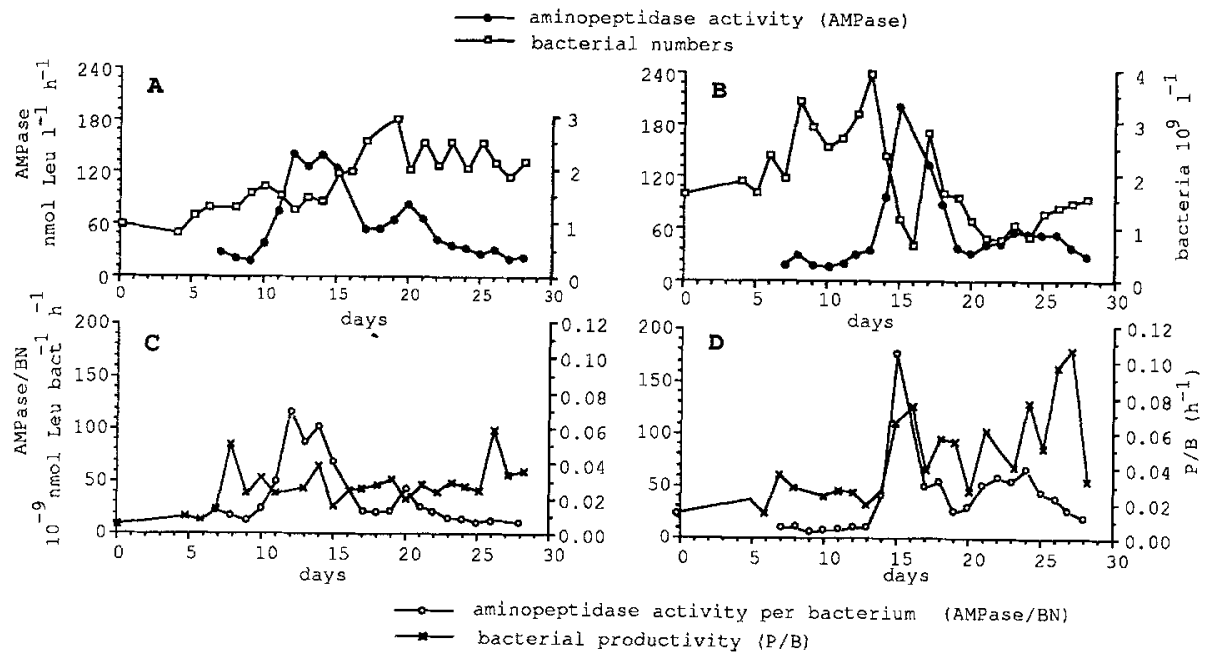

Fig. 3. Total extracellular proteolytic activity and bacterial biomass (A, B), and proteolytic activity per bacterium and bacterial productivity $(\mathbf{C}, \mathbf{D})$, in batches $\mathrm{L}($ left $)$ and $\mathrm{G}($ right $)$.

batch $L$ phytoplankton lysis batch $G$ phytoplankton grazing
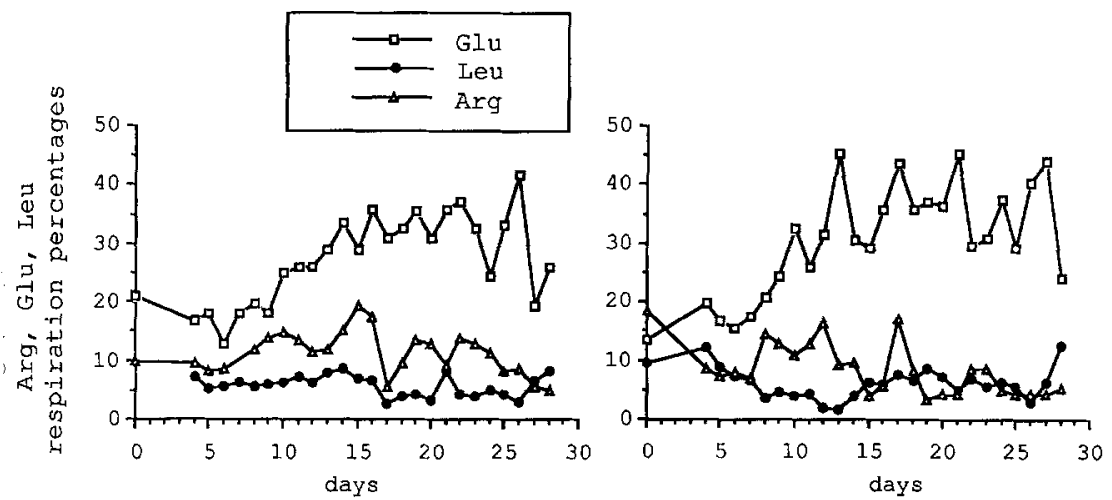

Fig. 4. Mineralization (as percentage respired) of leucine, arginine, and glutamate in batches L (left) and $\mathrm{G}$ (right).

(from $19.1 \%$ to $37.1 \%$ on day 22 ); in the $\mathrm{G}$ batch, in contrast, $45 \%$ of this amino acid was respired as early as day 13 . Then, the respiration percentages of glutamic acid varied greatly $(24-45 \%)$. In contrast, leucine was preferentially incorporated in proteins and was less respired in both batches. Leucine and arginine respiration percentages did not change significantly during the experiment in batch $\mathrm{L}$ (mean $5.7 \%$, HVC $30 \%$ for Leu, and $11.2 \%$, HVC $31 \%$ for Arg). In batch G, the Arg 


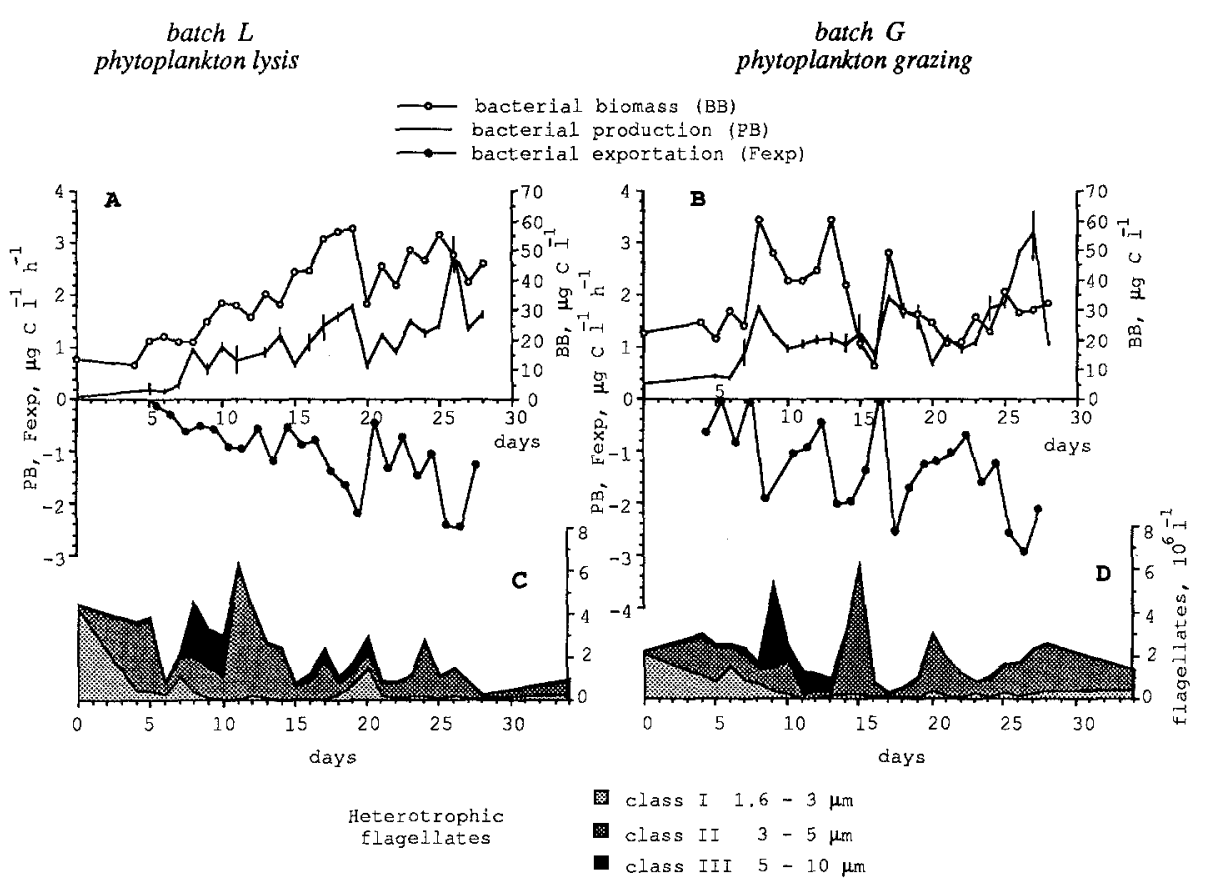

Fig. 5. A, B Bacterial biomass ( $\mu \mathrm{g} C \operatorname{liter}^{-1}$ ), bacterial production, and bacterial export ( $\mu \mathrm{g} \mathrm{C}$ liter ${ }^{-1} \mathrm{~h}^{-1}$ ) in batches $\mathrm{L}$ (left) and $\mathrm{G}(r i g h t)$. See methods for calculation of bacterial export. Abundance of nanoflagellates class I, II, III (C, D) are also reported for comparison with bacterial export. For bacterial production, bars represent differences between duplicates.

respiration percentage decreased significantly from $10.2 \%$ (confidence interval 7.9-12.5) to $5.4 \%$ (confidence interval 4.1-6.7) after day 17 .

Bacterial Production and Export. Bacterial production varied from 0.1 to $2.8 \mu \mathrm{g} \mathrm{C}$ liter ${ }^{-1} \mathrm{~h}^{-1}$, and 0.3 to $3.2 \mu \mathrm{g} \mathrm{C}$ liter $^{-1} \mathrm{~h}^{-1}$ in batches $\mathrm{L}$ and $\mathrm{G}$, respectively (Fig. 5A,B). As confirmed by time-series of bacterial productivity (Fig. 3C,D), bacterial production followed bacterial biomass more closely in batch $\mathrm{L}$ than in batch $\mathrm{G}$.

Bacterial export rates $\left(\mathrm{F}_{\text {exp }}\right)$ were of the same order of magnitude as bacterial production. In batch $G, F_{\exp }$ peaks coincided with net increases of nanoflagellate numbers (days 9 and 14, Fig. 5D), but in batch L, a nanoflagellate peak did not coincide with high values of $\mathrm{F}_{\text {exp }}$ (day 11, Fig. 5C).

During the aggregation phase (day 11) in batch L, the residual mortality of bacteria observed in the $<2 \mu \mathrm{m}$ fraction was higher than the total (residual + grazing) mortality rates observed in the unfiltered fraction (Fig. 6). Such experimental bias suggested a dependence of free-living bacteria on dissolved organic matter released after hydrolysis of phytoplankton detritus by attached bacteria.

\section{Trophic Transfer Calculations}

Bacteria-Protozoan Class I, II, and III Relationships. Nanoflagellates of class I, II, and III were all feeding on bacteria and were combined to estimate their carbon 


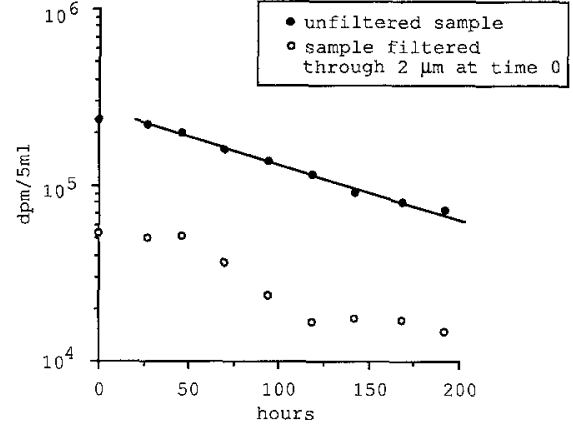

Fig. 6. Long term decrease in radioactivity in the cold TCA-insoluble fraction of a batch $\mathrm{L}$ sample after $\left[{ }^{3} \mathrm{H}\right]$ thymidine incorporation, filtered $(0)$ or not $(\bullet)$ through a $2-\mu \mathrm{m}$ filter at time zero. This bacterial mortality experiment was initiated on day 11 (during aggregation phase).

Table 1. Some estimates of carbon growth efficiencies based on characteristic ratios: $\mathrm{K}_{\text {flag }} / \mathrm{F}_{\text {exp }}$, nanoflagellates if feeding exclusively on bacteria; $\mathrm{PB} / \mathrm{K}_{\mathrm{Pt}}$, bacteria if feeding exclusively on all phytoplankton material; $\mathrm{PB} /\left[\mathrm{K}_{\mathrm{Pt}}-\left(\mathrm{F}_{\mathrm{exp}} \times 2\right)\right]$, bacteria if feeding exclusively on phytoplankton detrital material that is not used by nanoflagellates; $\mathrm{K}_{\mathrm{IVb}} / \mathrm{K}_{\mathrm{Pt}}$, protozoans of class IVb if feeding exclusively on $P$. tricornutum. See results for assumptions and choice of time intervals considered. $\mathrm{K}_{\text {flag }}$, daily net variation of nanoflagellate class I-II-III; $\mathrm{F}_{\text {exp }}$, bacterial exportation flux; $\mathrm{PB}$, bacterial production; $\mathrm{K}_{\mathrm{Pt}}$, daily net variation of $P$. tricornutum; $\mathrm{K}_{\mathrm{IVb}}$, daily net variation of nanoflagellate class $\mathrm{IV}_{\mathrm{b}}$ (all terms expressed in carbon units)

\begin{tabular}{|c|c|c|c|c|c|c|c|}
\hline & \multicolumn{4}{|c|}{ Batch L } & \multicolumn{3}{|c|}{ Batch G } \\
\hline Days & $7-8$ & $10-11$ & $15-16$ & $23-24$ & $13-14$ & $14-15$ & $19-20$ \\
\hline $\mathrm{K}_{\mathrm{flat}} / \mathrm{F}_{\exp }$ & $159 \%$ & $125 \%$ & $15 \%$ & $32 \%$ & $34 \%$ & $49 \%$ & $46 \%$ \\
\hline Days & \multicolumn{2}{|c|}{$4.5-14.5$} & \multicolumn{2}{|c|}{$15.5-23.5$} & $9-10$ & $14-15$ & \\
\hline $\mathrm{PB} / \mathrm{K}_{\mathrm{Pt}}$ & \multicolumn{2}{|c|}{$31.2 \%$} & \multicolumn{2}{|c|}{$48.4 \%$} & & & \\
\hline $\mathrm{PB}_{\mathrm{Pt}} l\left(\mathrm{~K}_{\mathrm{Pt}}-\left(\mathrm{F}_{\mathrm{exp}} \times 2\right)\right)$ & \multirow{2}{*}{\multicolumn{2}{|c|}{$64.5 \%$}} & & & & & \\
\hline $\mathrm{K}_{\mathrm{IVb}} / \mathrm{K}_{\mathbf{P t}}$ & & & & & $105 \%$ & $33 \%$ & \\
\hline
\end{tabular}

equivalent. Their growth efficiency, as reflected by the ratio $\mathrm{K}_{\text {flag }} / \mathrm{F}_{\text {exp }}$, was calculated during daily intervals showing large protozoan number increases (Table 1). The unrealistic ratios of $159 \%$ and $125 \%$ obtained in batch $\mathrm{L}$ during the aggregation phase confirmed that bacteria were not the exclusive diet for protozoans during this period. Nanoflagellates from classes I, II, and III fed on free bacteria, but also on bacteria attached to phytoplankton. They probably also engulfed aggregate detritus in their digestive vacuoles. Thus, considering this assumption and considering $40 \%$ as a reasonable growth yield for class I + II + III protozoans [11], it was estimated that bacteria would constitute only one-third (days 7-8) or one fourth (days 10-11) of their carbon demand during the aggregation phase.

Conversely, values of less than $50 \%$ were obtained for $\mathrm{K}_{\mathrm{flag}} / \mathrm{F}_{\mathrm{exp}}$ ratios after this aggregation phase in batch $\mathrm{L}$ and over the entire experiment duration in batch $\mathrm{G}$, and confirmed that bacteria largely satisfied the carbon demand of nanoflagellates (Table 1).

Phaeodactylum tricornutum-Bacteria Relationships. When lysis was the main degradative process, decaying $P$. tricornutum constituted the main carbon source for bacteria. Thus, the ratio of bacterial production to disappearing $P$. tricornutum 
$\left(\mathrm{PB} / \mathrm{K}_{\mathrm{Pt}}\right)$ constituted an estimate of the bacterial growth efficiency on available particulate material. $\mathrm{PB} / \mathrm{K}_{\mathrm{Pt}}$ calculated daily was highly variable during the experiment $(\mathrm{n}=21$; variation coefficient $=48 \%$ ). To interpret these data, this ratio was estimated at two time intervals determined according to the microcosm evolution. The first interval (days 4.5-14.5) corresponded to the aggregation phase, and the second one (days 15.5-27.5) corresponded to a steady state in decomposition without visible aggregates. The integrated $\mathrm{PB} / \mathrm{K}_{\mathrm{Pt}}$ ratios obtained were $31.2 \%$ and $48.4 \%$ for the first and the second phase, respectively (Table 1). If the fraction of detrital phytoplankton consumed directly by protozoa is taken into account (see above: bacteria-protozoa relationships), the phytoplankton disappearing $\left(\mathrm{K}_{\mathrm{Pt}_{\mathrm{P}}}\right)$ constitute a carbon source for both bacteria and protozoans. Thus, the bacterial carbon source equals $\mathrm{K}_{\mathrm{Pt}}$ minus carbon consumed by flagellates. I estimated (above) that for one part of bacterial carbon $\left(\mathrm{F}_{\text {exp }}\right)$, two other parts $\left(\mathrm{F}_{\text {exp }} \times 2\right)$ should come from phytoplankton detrital carbon to sustain nanoflagellate growth. Thus, the ratio $\mathrm{PB} /\left(\mathrm{K}_{\mathrm{Pt}}-\left(\mathrm{F}_{\exp } \times 2\right)\right)=64.5 \%$ is an alternative estimate of bacterial growth efficiency during the aggregation phase (Table 1).

\section{Discussion}

\section{Trophic Relationships}

During phytoplankton grazing, a classic scheme of predator-prey successions occurred. The two main trophic relationships, namely $P$. tricornutum-protozoans class IVb and bacteria-protozoans classes I, II, and III, were confirmed by the estimates of carbon growth efficiencies. In contrast, when the phytoplankton loss process was lysis, bacteria were not the exclusive diet for protozoans. In this experiment, another carbon source participated in up to two-thirds of protozoan carbon demand during the aggregation phase.

During both the aggregation and disaggregation phases observed during phytoplankton lysis, bacterial growth efficiencies on the available particulate material $\left(\mathrm{PB} / \mathrm{K}_{\mathrm{Pt}}\right.$ ratio) agreed with previously published data [30,31, 35], with respect to fresh phytoplankton detritus or nutrient-enriched microcosms. Nevertheless these growth efficiencies increased with time, and this is in contradiction to two observations: (1) the respiration percentage of glutamate increased during the experiment, and this amino acid is representative mainly of respiratory metabolism; and (2) the input of fresh algae was constant over time, but the degrading microcosms were not in a true steady state. Decomposition products that were refractory fractions probably accumulated in the lysis batch $\mathrm{L}$. Thus, the growth efficiency of bacteria should decrease with time, as the residual detrital material becomes more and more refractory $[30,31,35]$.

Conversely, if a direct utilization of detrital phytoplankton by protozoans is taken into account, the bacterial growth efficiency would decrease from $64.5 \%$ during aggregation phase, to $48.4 \%$ during the disaggregation phase (Table 1). Such a decrease of bacterial growth efficiency is in agreement with the observations on glutamate respiration and lability of detrital material described above. But the bacterial carbon growth efficiency of $64.5 \%$ obtained in this way is out of the range of $10-45 \%$ obtained on fresh or nitrogen-rich phytoplankton detritus [30, 31, 35]. The true bacterial growth efficiency during the aggregation phase probably ranged 
between $31.2 \%$ and $65 \%$. Effectively, the value of $65 \%$ was calculated, assuming (1) bacteria and phytoplankton detritus as sole carbon sources for protozoans and (2) a carbon growth efficiency of $40 \%$ for protozoans. Other sources of carbon for protozoans could also be present in aggregates. The ability of heterotrophic protozoans to incorporate colloids of different sizes has been demonstrated $[39,46]$. Alternatively, protozoans could feed on bacterial exopolymer secretion, or on dissolved organic matter adsorbed on the detritus aggregate, as hypothesized by Decho [10]. Additionally, in phytoplankton aggregates, protozoan growth efficiency could be lower because of food excess [22]. Thus, the contribution of phytoplankton detritus as a food source for protozoans would be lower, and the bacterial growth efficiency on phytoplankton detritus would be lower.

These results demonstrated the "short-cut" of nanoflagellates in the food chain during the aggregation phase: their growth was sustained by attached bacteria and carbon sources included in phytoplankton-detritus aggregates.

\section{Aminopeptidase Activity Sources and Controls}

Both phytoplankton decaying modes, lysis and grazing, allowed bacteria to reach about the same productivities $\left(0.03 \mathrm{~h}^{-1}\right)$, although aminopeptidase activity developed only in the presence of phytoplankton lysis. On the other hand, during the maximum intensity of bacterial grazing by protozoans, aminopeptidase activity increased. The development of this enzymatic activity had strong consequences on the bacterial metabolism. The hydrolyzed material constituted a new carbon source, and thus bacterial productivity increased by a factor of 3 . Protozoan succession modified qualitatively and quantitatively organic substrates for bacterial growth. Thus, in the grazing batch, the bacterial productivity ( $\mathrm{P} / \mathrm{B}$ ratio) never reached steady-state.

When phytoplankton is lysed, algal envelope breakage is a preliminary step before leakage of intracellular metabolites. Therefore, attachment of bacteria on the phytoplankton cells is a necessary step to initiate exoenzyme induction [8], decomposition, and subsequent bacterial growth. Billen [4] explained the delayed growth of bacterioplankton with respect to phytoplankton at the end of blooms as a lag phase necessary to exoenzymatic activity development. Aminopeptidase activity per cell was then maintained at high levels for several days because the marked leakage of proteins probably contributed to modification of the kinetic parameters, $K_{\mathrm{m}}$ and $V_{\mathrm{m}}[12,15,20]$. Leakage of dissolved combined amino acids has been observed during zooplankton grazing on freshwater algae in a nutrient-enriched enclosure [9].

Growth of free-living bacteria was extremely dependent on the exoenzymatic activity of attached bacteria. Bacteria from $2-\mu \mathrm{m}$ filtered sea water exhibited high mortality rates (Fig. 6), suggesting their strong dependency on the small molecules hydrolyzed by attached bacteria. Such 'uncoupled solubilization' has also been hypothesized for copepod fecal pellets [25]. In the same way, in deep water masses bacteria attached to marine snow play an important role for the nutrition of freeliving bacteria [43].

When grazing was the main phytoplankton loss process, the development of bacterial production and biomass was enhanced as soon as the inflow from the 
$P$. tricornutum culture was initiated. These bacteria used small molecules, as aminopeptidase activity did not develop during the first grazing phase by protozoa class IVb. Partially digested algal material contained in egested vacuoles, and direct protozoan excretion were the main sources of such small molecules.

The most interesting feature was the simultaneous increase of bacterial productivity and aminopeptidase activity per cell when bacterial predation by protozoans appeared particularly active. Diverse positive feedback effects of predation may favor bacterial growth. These could include nutrient regeneration [7], dissolved organic matter excretion [29], bacteria maintained under substrate limitation [50], physiological youth [21], and a chemostat effect [42]. In addition, modification of kinetic parameters by a suddenly elevated concentration of proteins was a possible explanation for the increase in extracellular proteolytic activity per bacterium. When the albumin concentration rises from 10 to $100 \mu \mathrm{g}$ liter ${ }^{-1}$, the $V_{\mathrm{m}}$ of aminopeptidase increases by a factor of 5 [15]. In a previous experiment, the difference between the dissolved organic nitrogen and the dissolved free amino acids varied greatly (Van Wambeke, submitted). Assuming this difference to be composed mainly of proteins [3] and assuming $1 \mu \mathrm{g} \mathrm{N}$-protein equivalent to 6.25 $\mu \mathrm{g}$ protein, protein fluctuations ranged from 150 to $535 \mu \mathrm{g} \mathrm{liter}^{-1}$. Such protein variations could also arise during the bacterial grazing phase.

Release of dissolved combined amino acids by Paraphysomonas imperforata was demonstrated by Nagata and Kirchman [29]. Assuming that growth carbon efficiencies and constitutive $\mathrm{C} / \mathrm{N}$ ratio were equal for both protozoan classes, nanoflagellates feeding on nitrogen-rich bacteria had a better chance of releasing organic nitrogen (i.e., potential substrates for proteolytic exoenzymes) than class $\mathrm{IVb}$ protozoans feeding on $P$. tricornutum (mean $\mathrm{C} / \mathrm{N}$ ratio 7-8). This difference may explain why aminopeptidase activity was not initiated during the $P$. tricornutum grazing phase.

Although enzymatic regulation of kinetic parameters and taxonomic selection is a possible explanation for the instability of aminopeptidase activity per bacterium, others are microenvironmental conditions and richness of detrital material. Development of a noticeable aminopeptidase activity in an $0.2-\mu \mathrm{m}$ filtrate is generally described as a filtration artifact [18]. Dissolved enzymatic activity was sometimes observed $[17,19,44]$, and has been attributed to lysed and senescent cells $[8,49]$. It is also conceivable that tertiary and/or quaternary structures of enzymes were maintained in the colloidal material associated in the phytoplankton detritus-bacteria aggregates obtained, or in egested protozoan vacuoles [36]. Such enzymes could exhibit their activities for some time, as already observed in sediments [28].

In conclusion, a separation of phytoplankton lysis and grazing in an experimental approach permitted quantification of the fate of the phytoplankton detritus in the microbial food web. Lysis is associated with formation of aggregated phytodetritus, which indirectly enhanced bacterial productivity by sustaining extracellular aminopeptidase activity on a longer time scale. Additionally, these aggregates participated, alternatively with bacteria, in the diet of heterotrophic nanoflagellates. Thus, both free bacterial production and nanoflagellate production could be sustained by phytoplankton aggregates in the euphotic zone before their exportation via sinking. Bacteria benefited directly from the pre-digested material released during phytoplankton grazing, without the metabolic costs of phytoplankton breakdown and exoenzymatic synthesis. In contrast, proteolysis activity increased during 
bacterial grazing by nanoflagellates, allowing a threefold increase in bacterial productivity.

Further experiments should focus on the capacity of each compartment of the food web to participate in phytoplankton loss (bacteria, protozoa, metazoa, and viruses) $[6,33,45]$ to produce directly utilizable or potentially hydrolyzable substrates for bacterial growth. At the least, the actual importance of nonbacterial sources of aminopeptidase activity in phytoplankton-derived detritus (lysates, egested vacuoles) should be better evaluated.

Acknowledgments. I am grateful to J. Garcin for help during sampling, and F. Rassoulzadegan for identification of some protozoa. I thank L.-A. Meyer-Reil for providing comments on an earlier version of the manuscript, and A. Bianchi, M. Bianchi, D. Moriarty, and an anonymous reviewer for helpful critical comments.

\section{References}

1. Azam F, Fenchel T, Field JG, Gray JS, Meyer-Reil LA, Thingstad F (1983) The ecological role of water-column microbes in the sea. Mar Ecol Prog Ser 10:257-263

2. Biddanda BA, Pomeroy LR (1988) Microbial aggregation and degradation of phytoplanktonderived detritus in seawater I. Microbial succession. Mar Ecol Prog Ser 42:79-88

3. Billen $G$ (1984) Heterotrophic utilization and regeneration of nitrogen. In: Hobbie JE, Williams PJ le B (eds) Heterotrophic activity in the sea. Plenum Press, New York, pp 313-355

4. Billen G (1990) Delayed development of bacterioplankton with respect to phytoplankton: a clue for understanding their trophic relationships. Arch Hydrobiol Beih Ergebn Limnol 34:191-201

5. Borsheim KY, Bratbak G (1987) Cell volume to cell carbon conversion factors for a bacterivorous Monas sp. enriched from sea water. Mar Ecol Prog Ser 36:171-175

6. Bratbak G, Heldal M, Norland S, Thingstad TF (1990) Viruses as partners in spring blooms in microbial trophodynamics. Appl Environ Microbiol 56:1400-1405

7. Caron DA, Goldman JC, Dennet MR (1988) Experimental demonstration of the roles of bacteria and bacterivorous protozoa in plankton nutrient cycles. Hydrobiologia 159:27-40

8. Chrost RJ (1990) Microbial ectoenzymes in aquatic environments. In: Overbeck J, Chrost R (eds) Aquatic microbial ecology, biochemical and molecular approaches. Springer-Verlag, pp 47-78

9. Chrost RJ, Rai H (1993) Ectoenzyme activity and bacterial secondary production in nutrientimpoverished and nutrient-enriched freshwater mesocosms. Microb Ecol 25:131-150

10. Decho AW (1993) Microbial exopolymer secretions in ocean environments: their role(s) in food webs and marine processes. Oceanogr Mar Biol Annu Rev 28:73-154

11. Fenchel T (1987) Ecology of protozoa. The biology of free-living phagotrophic protists. SpringerVerlag, Berlin

12. Fontigny A, Billen G, Vives-Rego J (1987) Some kinetic characteristics of exoproteolytic activity in coastal sea water. Est Coast Shelf Sci 25:127-133

13. Fuhrman JA, Azam F (1982) Thymidine incorporation as a measure of heterotrophic production in marine surface waters. Evaluation and field results. Mar Biol 66:109-120

14. Fukami K, Simidu U, Taga N (1981) Fluctuation of the communities of heterotrophic bacteria during the decomposition process of phytoplankton. J Exp Mar Biol Ecol 55:171-184

15. Halemejko GZ, Chrost RJ (1986) Enzymatic hydrolysis of proteinaceous particulate and dissolved material in an eutrophic lake. Arch Hydrobiol 107:1-21

16. Hansen L, Krog GF, Sondergaard M (1986) Decomposition of lake phytoplankton. 1. Dynamics of short-term decomposition. Oikos 46:37-44

17. Hashimoto S, Fujiwara K, Fiwa K, Saino T (1985) Distribution and characteristics of carboxypeptidase activity in pond, river, and seawaters in the vicinity of Tokyo. Limnol Oceanogr 30:631645 
18. Hoppe HG (1983) Significance of exoenzymatic activities in the ecology of brackish water: measurements by means of methyl-umbelliferyl substrates. Mar Ecol Prog Ser 11:299-308

19. Hoppe HG (1986) Relations between bacterial extracellular enzyme activities and heterotrophic substrate uptake in a brackish water environment. In: GERBAM (ed) Actes de Colloques, 3, IFREMER-CNRS, 2ème Colloque International de Bactériologie Marine, Brest, pp 119-128

20. Hoppe HG, Kim SJ, Gocke K (1988) Microbial decomposition in aquatic environments: combined process of extracellular enzyme activity and substrate uptake. Appl Environ Microbiol 54:784-790

21. Johannes RE (1965) Influence of marine protozoa on nutrient regeneration. Limnol Oceanogr 10:434-442

22. Jumars PA, Penry DL, Baross JA, Perry MA, Frost BW (1989) Closing the microbial loop: dissolved carbon pathway to heterotrophic bacteria from incomplete ingestion, digestion, and absorption in animals. Deep Sea Res 36:483-495

23. Karner M, Fuks D, Herndl GJ (1992) Bacterial activity along a trophic gradient. Microb Ecol 24:243-257

24. Keller AA, Riebesell U (1989) Phytoplankton carbon dynamics during a winter-spring diatom bloom in an enclosed marine ecosystem: primary production, biomass, and loss rates. Mar Biol 103:131-142

25. Lawrence SG, Ahmad A, Azam F (1993) Fate of particle-bound bacteria ingested by Calanus pacificus. Mar Ecol Prog Ser 97:299-307

26. Legendre L, Le Fèvre J (1989) Hydrodynamical singularities as control of recycled versus export production in the oceans. In: Berger WH, Smetacek VS, Wefer G (eds) Dahlem workshop on productivity of the ocean, present and past. John Wiley \& Son, Ltd., Berlin, pp 49-63

27. Lucas MI (1986) Decomposition in pelagic marine ecosystems. J Limnol Soc Sth Afr 12:99-122

28. Meyer Reil LA (1981) Enzymatic decomposition of proteins and carbohydrates in marine sediments. Methodology and field observations during spring. Kieler Meeresforsch, Sonderh 5:311317

29. Nagata T, Kirchman L (1991) Release of dissolved free and combined amino acids by bacterivorous marine flagellates. Limnol Oceanogr 36:433-443

30. Newell RC, Lucas ML, Linley EAS (1981) Rate of degradation and efficiency of conversion of phytoplankton debris by marine microorganisms. Mar Ecol Prog Ser 6:123-136

31. Newell RC, Linley EAS, Lucas ML (1983) Bacterial production and carbon conversion based on salt marsh plant debris. Est Coast Shelf Sci 17:405-419

32. Porter KG, Feig YS (1980) The use of DAPI for identifying and counting aquatic microflora. Limnol Oceanogr 25:943-948

33. Proctor LM, Fuhrman JA (1991) Role of viral infection in organic particle flux. Mar Ecol Prog Ser 69:133-142

34. Riemann B, Bjørnsen PK, Newell S, Fallon R (1987) Calculation of cell production of coastal marine bacteria based on measured incorporation of $\left[{ }^{3} \mathrm{H}\right]$ thymidine. Limnol Oceanogr 32:471-476

35. Robinson JD, Mann KH, Novitsky JA (1982) Conversion of the particulate fraction of seaweed detritus to bacterial biomass. Limnol Oceanogr 27:1072-1079

36. Rosso AL, Azam F (1987) Proteolytic activity in coastal oceanic waters: depth distribution and relationships to bacterial populations. Mar Ecol Prog Ser 41:231-240

37. Servais $P$, Billen G, Vives-Rego J (1985) Rate of bacterial mortality in aquatic environments. Appl Environ Microbiol 49:1448-1454

38. Sheldon RW, Rassoulzadegan F (1987) A method for measuring plankton production by particle counting. Mar Microb Food Webs 2:29-44

39. Sherr EB (1988) Direct use of high molecular weight polysaccharides by heterotrophic flagellates. Nature 335:348-351

40. Sherr EB, Sherr BF (1983) Double staining epifluorescence technique to assess FDC and bacteriovory in natural populations of heterotrophic microprotozoa. Appl Environ Microbiol 46:13881393

41. Simon M, Azam F (1989) Protein content and protein synthesis rates of planktonic marine bacteria. Mar Ecol Prog Ser 51:201-213

42. Sinclair JL, Alexander MA (1989) Effect of protozoan predation on relative abundance of fast- and slow-growing bacteria. Can J Microbiol 35:578-582 
43. Smith DC, Simon M, Alldredge AL, Azam F (1992) Intense hydrolytic enzyme activity on marine aggregates and implications for rapid dissolution. Nature 359:139-142

44. Somville M, Billen G (1983) A method for determining exoproteolytic activity in natural waters. Limnol Oceanogr 28:190-193

45. Suttle CA, Chan AM, Cottrel MT (1990) Infection of phytoplankton by viruses and reduction of primary productivity. Nature 347:467-469

46. Tranvik LJ, Sherr EB, Sherr BF (1993) Uptake and utilization of 'colloidal DOM' by heterotrophic flagellates in seawater. Mar Ecol Prog Ser 92:301-309

47. Van Boekel WHM, Hansen FC, Riegman R, Bak RPM (1992) Lysis-induced decline of a Phaeocystis spring bloom and coupling with the microbial food wed. Mar Ecol Prog Ser 81:269276

48. Van Wambeke F, Bianchi MA (1985) Dynamics of bacterial communities and qualitative evolution of heterotrophic bacteria during the growth and decomposition processes of phytoplankton in an experimental marine ecosystem. J Exp Mar Biol Ecol 86:119-137

49. Vives-Rego J, Billen G, Fontigny A, Somville M (1985) Free and attached proteolytic activity in water environments. Mar Ecol Prog Ser 21:245-249

50. Wright RT, Coffin RB (1984) Measuring microzooplankton grazing on planktonic marine bacteria by its impact on bacterial production. Microb Ecol 10:137-149 